\title{
FABRICATION OF CERAMIC MEMBRANE CHROMATOGRAPHY FOR BIOLOGICS PURIFICATION
}

\author{
Maizirwan Mel ${ }^{1}$, Fouad R.H. AbdeEn ${ }^{1}$ AND IIS SOPYAN ${ }^{2}$ \\ ${ }^{1}$ Department of Biotechnology Engineering, \\ ${ }^{2}$ Department of Manufacturing and Materials Engineering, \\ International Islamic University Malaysia \\ P.O. Box 10, 50728 Kuala Lumpur, Malaysia.
}

maizirwan@iium.edu.my

\begin{abstract}
Chromatography is one of the most important separation processes of choice for the recovery/purification of proteins and complex bio-structures. Fabrication of chromatographic membranes and their efficiency in the chromatography process has been the subject of many recent researches. In this study, a coin-like, $13 \mathrm{~mm}$ diameter and $3 \mathrm{~mm}$ thick, ceramic membrane was fabricated to be used as a chromatographic medium. The membrane is used to replace the conventional resin-based chromatography columns. Hydroxyapatite (HA) powder was used as a material for the membrane fabrication. In this project, a HA powder was produced using starch as pore creating agents. Characterization processes were done for the ceramic membrane using the suitable apparatuses. Three parameters of the fabrication process (starch wt \%, compaction pressure and sintering temperature) were manipulated to optimize the performance of the membrane. The fabricated membrane was placed in a (FPLC) system to be tested for its performance as an adsorptive membrane. (IMAC) process was run by immobilizing $\mathrm{Ni}^{2+}$ ions at the membrane particles surfaces. NP protein of the (NDV) was used to test the membrane's ability to bind Histidine-tagged proteins. The optimum set of process parameters that yielded in the highest porosity and good chromatogram was determined to be $5 \mathrm{wt} \%$ starch, $3000 \mathrm{psi}$ compaction pressure and $1100^{\circ} \mathrm{C}$ sintering temperature.
\end{abstract}

ABSTRAK: Kromatografi merupakan satu daripada proses pengasingan yang penting yang dipilih untuk perolehan/penapisan protein dan biostruktur yang kompleks. Pemfabrikatan membran kromatografi dan kecekapannya dalam proses kromatografi merupakan fokus beberapa kajian terkini. Dalam kajian ini, membran seramik berbentuk duit syiling, berdiameter $13 \mathrm{~mm}$ dengan ketebalan $3 \mathrm{~mm}$, direka untuk digunakan sebagai perantara kromatografi. Membran ini digunakan untuk menggantikan turus kromatografi berasaskan resin yang lazim. Serbuk hidroksiapatit $(H A)$ digunakan sebagai bahan pemfabrikatan membran. Dalam projek ini, serbuk $H A$ dihasilkan menggunakan kanji sebagai agen penghasilan liang. Proses pencirian dilakukan terhadap membran seramik menggunakan radas yang sesuai. Tiga parameter proses pemfabrikatan (peratusan berat kanji, tekanan padatan dan suhu pensinteran) dimanipulasikan untuk mendapatkan prestasi membran yang optima. Membran yang difabrikatkan diletakkan dalam sistem FPLC (Fast Protein Liquid Chromatography) untuk diuji prestasinya sebagai membran serap. Proses IMAC (Immobilized Metal Affinity Chromatography) dijalankan dengan memegunkan ion $\mathrm{Ni}^{2+}$ pada permukaan zarah membran. Nucleoprotein dari NDV (Newcastle disease virus) digunakan untuk menguji kebolehan membran terikat dengan protein yang dilabelkan dengan Hisditina. Set parameter proses yang optima yang menghasilkan keliangan tertinggi dan kromatogram yang baik ditentukan pada berat kanji $5 \%$, tekanan padatan 3000 psi dan suhu pensinteran $1100^{\circ} \mathrm{C}$ 
KEYWORDS: membrane chromatography; porous ceramic membrane; IMAC; hydroxyapatite

\section{INTRODUCTION}

The development of methods and techniques for the purification of biological products has been a crucial requirement for many of the improvements made in biotechnology. Most of the products of biotechnology are proteins, nucleic acids, enzymes and antibodies and these products must be prepared in large volumes and purified form [1].

In the purification process, biomolecules are being separated or grouped according to their common characteristics. Different types of proteins, for example, share some similarities and also have certain differences. While protein similarities are used to purify them away from the non-protein contaminants, their differences are used to purify one protein from another.

According to the standard requirements and regulations imposed by FDA and cGMP, downstream purification processing of proteins from biological mixtures should preserve the proteins' structure and biological activity [2]. Thus, the fabrication of purification media from biocompatible material has been one of the most challenging matters in the recent membrane separation technologies.

One of the most important methods used for protein purification is chromatography. It has been proven that chromatography is the best method to purify recombinant proteins [3]. According to some academics, "Membrane chromatography has increasingly been reported as a potentially advantageous tool to purify proteins" [4]. Although conventional resin-based chromatography columns dates earlier than membrane chromatography, the later one has been studied as an alternative for the first over decades [5].

Adsorptive membranes has been fabricated with a variety of adsorptive mechanisms (e.g. ion-exchange, hydrophobic, reversed phase, affinity). Adsorptive membrane chromatography is favorable over the resin-based chromatography column because of the long diffusion times that often occur in the later one.

Fluid mechanics interaction with mass transfer is critical in the design of chromatographic systems. To get any development in a chromatographic system we should maximize the mass transfer rates while minimizing momentum transfer and/or pressure drop. Comparing with the traditional resin-based column, membrane has bigger pores, which makes the proteins can access the binding site on the membrane surface by directly bulk convection and with very little pore diffusion [5].

It has been proven that some ceramic materials are very useful as chromatographic media. Ceramic hydroxyapatite, (coated and sintered with certain materials) is amongst the most common ceramic materials to be used in this field [6]. The purpose of this study was to develop a ceramic membrane which can be used in the purification of the various biochemical molecules applying the principles of chromatography.

\section{MATERIALS AND METHODS}

\subsection{Nucleocapsid Protein of Newcastle Disease Virus (NP-NDV)}

A Histidine tagged recombinant form of NP was obtained from the Bioprocess Engineering Laboratory in the Department of Biotechnology Engineering of IIUM. 


\subsection{Adsorptive Mechanism/Mode}

The material chosen for the fabrication of the membrane was ceramic hydroxyapatite (CHT). Since our product to be purified is Histidine tagged protein, the adsorption mechanism to be applied is metal affinity chromatography. The Histidine tails will have a great affinity for CHT calcium [7]. The principle of IMAC was based on the formation of weak coordination bonds between metal ions immobilized on a chromatographic support and the exposed residues of target proteins, mainly Histidine (His) residues. The additional His tag confers the fusion protein specific binding strength to divalent metal ions immobilized on the adsorption column/membrane. The most commonly used metal ions in IMAC are $\mathrm{Ni}^{2+}, \mathrm{Zn}^{2+}, \mathrm{Cu}^{2+}, \mathrm{Co}^{2+}$ and $\mathrm{Ca}^{2+}$, which are classified as transition metal ions [8].

These metal ions are chelated to a multidentate ligand immobilised onto a support material [9]. The most commonly used multidentate ligand is iminodiacetic acid (IDA) and nitrilotriacetic acid (NTA). Nickel ions have been chosen to be immobilised to the adsorbent of this study because nickel ions are most often used in IMAC and has the higher affinity to the His residues of target proteins [10].

\subsection{Fabrication of Ceramic Membrane}

The membrane of this study is fabricated from HA powder obtained from the market. Then the powder is mixed with the pore creating agents, compacted and sintered. Porous HA ceramics with different pore morphology are usually fabricated, utilizing organic substances, such as starch, as the fugitive agents. The resultant porous ceramics usually have rod-shaped or equiaxial pore morphology. The mechanical properties were investigated. The strength decreased considerably when small amounts of starch were added; however, further increase in the starch content only caused a moderate decrease in strength.

In this study, powder form of HA was obtained from the market and was mixed with starch as pore creating agents prior to sintering. Starch when used as pore creating agents usually leads to the formation of pores in the range of $0.09-4.00 \mu \mathrm{m}$. The starch was mixed with the powder using the ball milling method.

A ball mill is a type of mixer and grinder in the same time used to grind materials into extremely fine powder. The ball mill machine used in this study is the Planetary Mill Pulverisette 5 ball milling machine produced by Fritsch Company. Operating at $150 \mathrm{rpm}$ the Planetary Mill Pulverisette 5 can produce starch with fineness of $0.1-1.0 \mu \mathrm{m}$. Two types of samples were prepared namely, $2 \mathrm{wt} \%$ and $5 \mathrm{wt} \%$ starch.

The powder obtained after mixing was compacted using a mold of $13 \mathrm{~mm}$ diameter and adjustable height made of hardened steel. The thickness of the membrane wa controlled by manipulating the amount of the powder added in the mold. In this study the compaction process was done using the Manual Pellet Press produced by Carver Inc. The machine can apply compaction pressure up to $4000 \mathrm{psi}$. In this study the fabricated membrane was compacted using too levels of compaction, the lower level with $3000 \mathrm{psi}$ and the higher one with 4000 psi.

The compacted membrane was sintered at high temperatures (below its melting point) so that the particles will adhere to each other yielding in high mechanical strength. Compared to other methods of fabricating ceramic materials, sintering is considered a simple method that provides a denser and stronger product. In this study, the compacted membranes were sintered at two temperatures, $1000^{\circ} \mathrm{C}$ and $1100^{\circ} \mathrm{C}$. The compacted membranes were heated from room temperature to $600^{\circ} \mathrm{C}$ at a rate of $25^{\circ} \mathrm{C}$ per minute, 
then held for one hour before heating again to the final sintering temperature (1000 and $1100^{\circ} \mathrm{C}$ ) at the same rate. The membranes then were held at the final sintering temperature for one hour and left to cool inside the furnace.

\subsection{Membrane Characterization}

FESEM was used to analyze the morphology, fracture study, interface behavior, localization of boundaries between regions of different atomic numbers, sample contamination, quantitative and qualitative elemental analysis, grain orientation, texture and phase identification. The sample that was analyzed was coated using Autofine Coacter JFC-1600. JEOL JSM-6700F Field Emission Scanning Electron Microscopy (FESEM) performs using a light microscopy; a microscope employing both dark and bright field reflected illumination.

The strength/hardness of the material was measured using the Micro-Vicker's hardness machine produced by Wilson-Wolpert. And porosity was calculated after measuring the apparent density and comparing it with the theoretical density. The density of the membrane was measured using density meter brand AND. The porosity is then calculated by the following equation:

$$
\begin{array}{ll}
\text { Relative Density } & =\rho_{\text {app }} / \rho_{\text {th }} \times 100 \\
\% \text { Porosity } & =100 \%-\text { Relative Density }
\end{array}
$$

where

$\rho_{\text {app: }}$ Measured density after sintering.

$\rho_{\text {th: }}$ Theoretical density of HA equals $3.10 \mathrm{~g} / \mathrm{m}^{3}$

\subsection{Method of Analysis}

In this study three parameters, starch percentage, compaction pressure, and sintering temperature, were varied to optimize the performance of the membrane. Each parameter has been used in two levels, high and low. The analysis of the process was carried out using the 2 Level Factorial Design of the Design Expert Software. Table 1 shows the different parameter variation.

Table 1: Process Parameters of Ceramic Membrane Fabrication with 2 Levels Factor.

\begin{tabular}{|l|l|l|l|}
\hline Component/Factor & \multirow{2}{*}{ Unit } & Level \\
\cline { 3 - 4 } & & -1 (low) & 1 (high) \\
\hline Sintering Temp. & ${ }^{\circ} \mathrm{C}$ & 1000 & 1100 \\
\hline Starch Percentage & $\%$ & 2 & 5 \\
\hline Compaction Pressure & psi & 3000 & 4000 \\
\hline
\end{tabular}

\subsection{Testing the Fabricated Membrane Using FPLC System}

The purification process of the NP protein from clarified feedstock was done using a XK 16/20 cartridge produced by Amersham Biosciences. A sufficient number of the ceramic membranes were packed into the XK 16/20 cartridge with a bed height of $10 \mathrm{~cm}$. The fabricated membrane is tested for its ability to perform as a chromatographic media using FPLC system. As mentioned earlier in this study, purification process of the NP protein from ultra-filtered solution is used to test the membrane. After being packed with 
the fabricated membrane, the XK 16/20 was connected to the FPLC system using the suitable fittings. The membrane then was charged with $\mathrm{Ni}^{2+}$ ions and equilibrated with binding buffer $(0.02 \mathrm{M}$ sodium phosphate, $0.5 \mathrm{M}$ sodium chloride, $\mathrm{pH} 8.0)$ at a flow

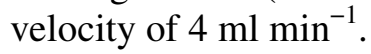

After the column was placed in the AKTA purifier, clarified and ultra-filtered E. coli feedstock was applied onto the column at the same flow velocity. Then bed was washed to remove loose bound protein using the binding buffer at a flow velocity of $4 \mathrm{ml} \mathrm{min}^{-1}$. The adsorbents were first eluted with elution buffer $1(50 \mathrm{mM}$ Imidazole in $0.02 \mathrm{M}$ Sodium Phosphate, $0.5 \mathrm{M}$ Sodium Chloride, $\mathrm{pH} 8.0$ ) at a flow velocity of $1.5 \mathrm{ml} \mathrm{min}^{-1}$ to remove the contaminating protein. The bound NP protein was eluted with elution buffer 2 (350 mM Imidazole in 0.02 M Sodium Phosphate, 0.5 M Sodium Chloride, $\mathrm{pH}$ 8.0) at a

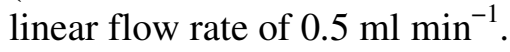

The column/membranes were regenerated for further use by pumping the washing buffer $(0.5 \mathrm{M}$ sodium hydroxide and $1 \mathrm{M}$ sodium chloride) into the column with a flow velocity of $2 \mathrm{ml} \mathrm{min}^{-1}$ for $4 \mathrm{~min}$, followed by rinsing with distilled water. The adsorbent (membrane) was preserved in $20 \%$ ethanol. Upon completing the chromatography run the chromatogram of the process is obtained and is analyzed. The presence of sharp peaks is a sufficient indication that the membrane functioned as a chromatographic media and has adsorbed the histidine-tagged NP protein.

\section{RESULTS AND DISCUSSION}

\subsection{Characterization Results}

At the end of this study coin-like ceramic membranes were produced. Different membranes, fabricated by changing several parameters (Starch wt $\%$, sintering temperature and compaction pressure), were first characterized then tested for their ability to purify a histidine-tagged NP protein. The characterization results are shown in Figre1.a and Figure 1.b. In addition, Wilson-Wolpert Micro-Vicker's hardness machine was used to measure the hardness of eight different samples; the results are shown in Table 2.



a)

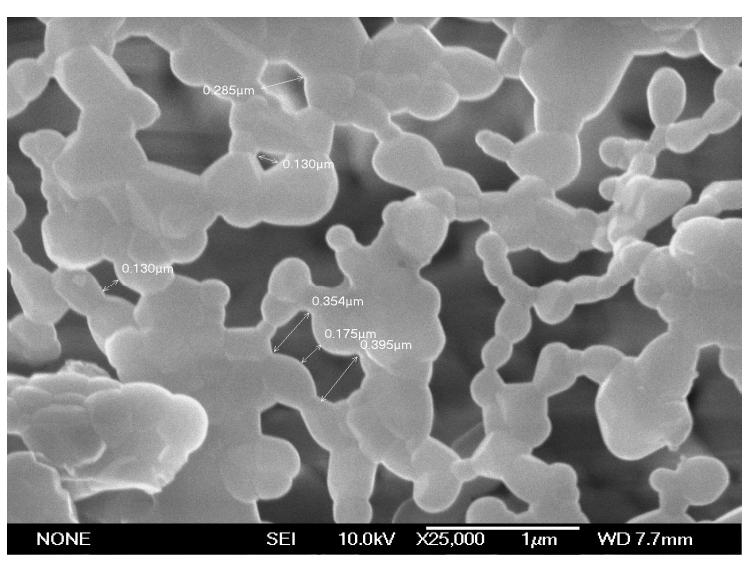

b)

Figure 1: HA Membrane with 5wt $\%$ starch, sintered at $1100^{\circ} \mathrm{C}$ and compacted at 4000 psi a) Whole micro structure view shows a surface fracture. b) Magnified image shows the pore diameter $(130 \mathrm{~nm}-395 \mathrm{~nm})$. 
From Table 2, it is obvious that the sintering temperature has a great effect on the hardness of the material. Ceramic HA membranes sintered at $1100^{\circ} \mathrm{C}$ have Vickers hardness of 590-690 $\mathrm{MPa}$ which is much greater than that to membranes sintered at $1000^{\circ} \mathrm{C}(18-27 \mathrm{MPa})$. Since withstanding high pressure is a key requirement for a chromatography membrane, sintering ceramic membranes at $1100^{\circ} \mathrm{C}$ rather than $1000^{\circ} \mathrm{C}$ is much more favorable for the application of chromatography.

In fact, increasing the porosity of chromatography membrane means that increasing its performance efficiency. Equations 1 and 2 were used to calculate the porosity of eight different samples. The porosity was implemented as the response to be optimized using the Design Expert software. The porosity response with the three various variables are presented in Table 3.

Table 2: Values of Vickers hardness for the eight different samples.

\begin{tabular}{|c|c|c|c|c|}
\hline \multirow{2}{*}{$\begin{array}{c}\text { Sample } \\
\text { No. }\end{array}$} & $\begin{array}{c}\text { Sintering } \\
\text { Temp. }\left({ }^{\circ} \mathrm{C}\right)\end{array}$ & $\begin{array}{c}\text { Starch Percentage } \\
(\mathrm{wt} \%)\end{array}$ & $\begin{array}{c}\text { Compaction } \\
\text { Pressure (psi) }\end{array}$ & $\begin{array}{c}\text { Response } \\
\text { Vickers Hardness } \\
(\mathrm{MPa})\end{array}$ \\
\hline 1 & 1000 & 2 & 4000 & 27 \\
\hline 2 & 1100 & 2 & 4000 & 690 \\
\hline 3 & 1000 & 5 & 4000 & 21 \\
\hline 4 & 1100 & 5 & 4000 & 670 \\
\hline 5 & 1000 & 2 & 3000 & 21 \\
\hline 6 & 1100 & 2 & 3000 & 610 \\
\hline 7 & 1000 & 5 & 3000 & 18 \\
\hline 8 & 1100 & 5 & 3000 & 590 \\
\hline
\end{tabular}

Table 3: Experimental design for ceramic membrane chromatography using Design Expert software with the porosity percentage response.

\begin{tabular}{|c|c|c|c|c|c|c|c|c|}
\hline \multirow[b]{3}{*}{ Run } & \multicolumn{6}{|c|}{ Factors } & \multirow{2}{*}{\multicolumn{2}{|c|}{$\begin{array}{r}\text { Response } \\
\text { Porosity (\%) }\end{array}$}} \\
\hline & \multicolumn{2}{|c|}{ Sintering Temp. (C) } & \multicolumn{2}{|c|}{ Starch Percentage $(\%)$} & \multicolumn{2}{|c|}{ Comp. Press.(psi) } & & \\
\hline & Actual & Code & Actual & Code & Actual & Code & Exp. & Pre.* \\
\hline 1 & 1000 & -1 & 2 & -1 & 4000 & 1 & 2.58 & 2.76 \\
\hline 2 & 1100 & 1 & 2 & -1 & 4000 & 1 & 5.97 & 5.92 \\
\hline 3 & 1000 & -1 & 5 & 1 & 4000 & 1 & 7.29 & 7.11 \\
\hline 4 & 1100 & 1 & 5 & 1 & 4000 & 1 & 11.06 & 11.11 \\
\hline 5 & 1000 & -1 & 2 & -1 & 3000 & -1 & 4.29 & 4.11 \\
\hline 6 & 1100 & 1 & 2 & -1 & 3000 & -1 & 8.58 & 8.63 \\
\hline 7 & 1000 & -1 & 5 & 1 & 3000 & -1 & 8.29 & 8.47 \\
\hline 8 & 1100 & 1 & 5 & 1 & 3000 & -1 & \begin{tabular}{|l|l}
13.87 \\
\end{tabular} & 13.82 \\
\hline
\end{tabular}


From Table 3, we can notice that, in general, higher porosities are attained for samples sintered at higher temperature. Samples sintered at $1100^{\circ} \mathrm{C}$ have higher porosities ranging from 13.87-5.97. However, the range of porosity for samples sintered at $1000^{\circ} \mathrm{C}$ was 8.29-2.58. After preparing 8 different samples, the data of the porosity was recorded.

Prediction of results' validity was estimated using the F-values of each parameter of the quadratic regression equation (Table 4). The most significant factors are the starch percentage (wt \%) with F-value probability less than 0.0015 , then Sintering temperature 0.0019. In general, most of the parameters are considered significant (Probability $>\mathrm{F}$ value is less than 0.15). It is obvious that all the three parameters are significant to the change in the porosity of the sample. As for the 8 different runs performed in this study, the maximum porosity (13.82) was obtained at 5 wt $\%$ starch percentage, 3000 psi compaction pressure and $1100^{\circ} \mathrm{C}$ sintering temperature.

Table 4: Analysis of variance (ANOVA).

\begin{tabular}{|c|c|c|c|c|c|c|}
\hline Source & $\begin{array}{c}\text { Sum of } \\
\text { Squares }\end{array}$ & DOF & $\begin{array}{c}\text { Mean } \\
\text { Square }\end{array}$ & F-Value & $\begin{array}{c}\text { Proba- } \\
\text { bility }> \\
\text { F }\end{array}$ & Note \\
\hline Model & 91.37773 & 5 & 18.27555 & 270.1969 & 0.0037 & significant \\
\hline A (Temp.) & 36.26223 & 1 & 36.26223 & 536.1231 & 0.0019 & significant \\
\hline B (Starch \%) & 45.58585 & 1 & 45.58585 & 673.9692 & 0.0015 & significant \\
\hline $\begin{array}{c}\text { C (Compaction } \\
\text { Pressure) }\end{array}$ & 8.260146 & 1 & 8.260146 & 122.1231 & 0.0081 & significant \\
\hline AB & 0.351717 & 1 & 0.351717 & 5.2 & 0.1502 & significant \\
\hline AC & 0.917794 & 1 & 0.917794 & 13.56923 & 0.0664 & significant \\
\hline Residual & 0.135276 & 2 & 0.067638 & - & - & - \\
\hline Corrected Total & 91.51301 & 7 & - & - & - & - \\
\hline
\end{tabular}

\subsection{Analysis of the Ceramic Membrane Performance as Chromatographic Media}

The performance of the ceramic membrane was analyzed by running the FPLC process for the purification of NP from NDV as mentioned earlier in this study. As was expected, a high percentage of the NP protein, fed to the ceramic membrane, were bound to the $\mathrm{Ni}^{2+}$ ions immobilized at the membrane particles surfaces indicated by the patterns changes of the obtained chromatograms.

In this study, the only indication of good membrane performance is determined by analyzing the chromatogram of the process. If a sharp peak is attained that means the membrane has functioned as IMAC chromatography media [11]. After membranes characterization, it was obvious that membranes sintered at $1000^{\circ} \mathrm{C}$ have a very low Vickers Hardness values. Consequently, those membranes were damaged when subjected to a liquid pressure higher than $5 \mathrm{MPa}$. Hence, membranes sintered at $1100^{\circ} \mathrm{C}$ only were tested using the AKTA purifier (produced by Amersham Biosciences). 



Fig. 2: Process parameters effect on the porosity of the membrane. a) Process Model: A represents sintering temperature, $\mathrm{B}$ represents starch percentage and $\mathrm{C}$ represents compaction pressure. b) Temperature Interaction with starch concentration effect. c) Temperature interaction with compaction pressure effect. d) Interaction between the effects of starch percentage and compaction pressure on membrane porosity. 
The best sample that has functioned as a good chromatographic media is sample 8 . The corresponding chromatogram obtained using sample 8 is shown in Fig. 3. Analyzing the chromatogram, one can see that a sharp peak was obtained in the gradient elution area and another one is obtained at the constant level of high elution buffer concentration. Certainly, attaining the first peak is a clear indication of the good performance of this sample as a chromatographic media.

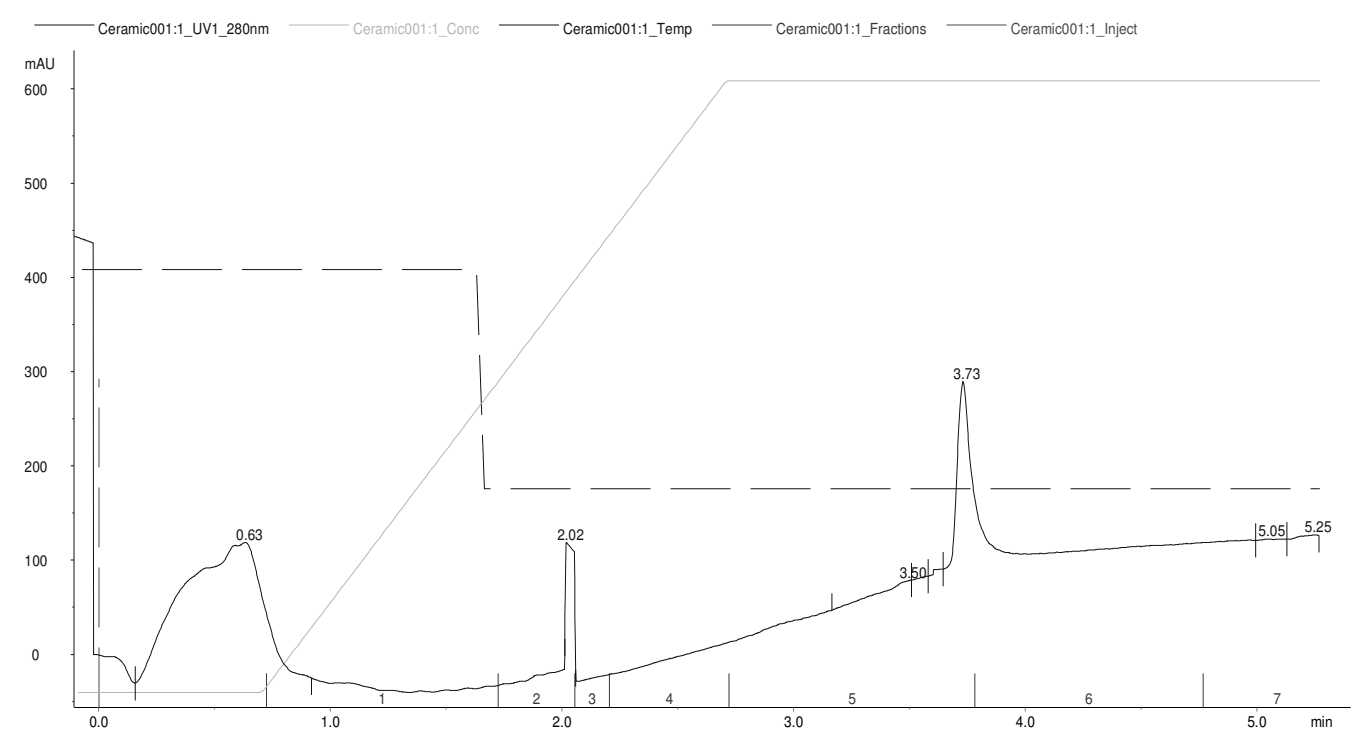

Fig. 3: Chromatogram obtained by running metal affinity chromatography after loading the FPLC system with sample no. 8.

\section{CONCLUSION AND RECOMMENDATIONS}

The three process parameters (Starch wt\%, sintering temperature and compaction pressure) manipulated to optimize the performance of the membrane were proven to be all significant. In the case of maximizing porosity, the optimum set of parameters was determined to be, $5 \mathrm{wt} \%$ starch percentage, 3000 psi compaction pressure and $1100^{\circ} \mathrm{C}$ sintering temperature. IMAC was run using four different membranes as chromatographic media in the FPLC system. The corresponding chromatograms were varied and have proven that the fabricated membrane is good chromatographic media. The best chromatogram was the one corresponding to the membrane sample with the maximum porosity.

For further improvements and optimizations in the performance of the product/membrane of this study, it will be useful to run the fabrication process at a wider range of parameters. Based on the results obtained by this study, it is advisable that sintering temperatures be ranging from $1100^{\circ} \mathrm{C}$ up to the highest value below the material's (HA) melting point $\left(1570^{\circ} \mathrm{C}\right)$. As for the compaction pressure it is advisable to vary it at a range lower than 3000 psi when using an axial press machine. Finally, pore creating agents percentage can be chosen in a range of higher than 5 wt $\%$ while accounting for the drop in the mechanical strength of the membrane. Other parameters that can be helpful in fabricating such a membrane can be the mixing time and size of pre creating agents. 


\section{ACKNOWLEDGEMENTS}

We would like to thank all the staff of the Kulliyyah of Engineering of IIUM for the helpful preparation of all necessary laboratories to carry out this study. Special thanks are due to Haji Sukiman Sengat and Mohd Hafizul Shaibon for their technical assistant.

\section{REFERENCES}

[1] Belter, P. A., Cussler, E.L., \& Hu, W. (1998): Bioseparations : Downstream processing for biotechnology. New York : Wiley.

[2] Robards, K., Haddad, P.R., Jacksonby, P.E., \& Robards, K. (1994). Principles and practice of modern chromatographic methods. London : Academic Press.

[3] Cao, L. (2005). Protein Separation with Ion-exchange Membrane Chromatography. A thesis submitted to Worcester Polytechnic Institute.

[4] Kundsen, L.H., \& Fahrner, R.L. (2001). Membrane ion-exchange chromatography for process-scale antibody purification. Journal of Chromatography A, 907, 145-154.

[5] Teeters, A.M., Root, W.T. \& Ligtfoot N. (2002). Performance and scale-up of adsorptive membrane chromatography. Journal of Chromatography A, 944, 129-139.

[6] Gangon, P. et al. (2006). A ceramic hydroxyapatite-based purification platform. BioProcess International.

[7] Wiederschain, G. (2007). Handbook pf affinity chromatography. Moscow: Biochemistry.

[8] Jiang, W. \&. Hearn, W. (1996). Protein interaction with immobilized metal ion affinity ligands under high ionic strength conditions. Anal Biochem 242, 45-54.

[9] Chaga, G.S. (2001). Twenty-five years of immobilized metal ion affinity chromatography: past, present and future. J Biochem Biophys Methods 49, 313334.

[10] Clemmitt, R.H. (1999). On-line monitoring of the purification of GST-(His) from an unclarified Escherichia coli homogenate within an immobilised metal affinity expanded bed. Bioseparation, 8,53-67.

[11] Gaberc-Porekar, V. \& Menart, V. (2001). Perspectives of immobilized-metal affinity chromatography J Biochem Biophys Methods, 49, 335-360. 